\title{
Saccharomyces cerevisiae strain associated to a fish culture additive: antifungal activity and AFBl adsorption potential
}

\author{
Saccharomyces cerevisiae associada a um aditivo de piscicultura: \\ atividade antifúngica e potencial de adsorção de AFBI
}

\author{
Juliana Alexandre laniceli ${ }^{(1)}$, Aline Maria Dourado Rodrigues² (1) , João Farias Sousa Junior² (iD, \\ Rafael Gomes Abreu Bacelar ${ }^{3 *}$ (1), Maria Christina Sanches Muratori ${ }^{4}$
}

\begin{abstract}
Saccharomyces cerevisiae is widely applied as a probiotic in aquaculture activities, due to its ability to decontaminate the mycotoxin Aflatoxin $B_{1}\left(A_{F} B_{1}\right)$. From this point, the present study aimed to evaluate the antifungal and anti-aflatoxigenic activities of inactivated Saccharomyces cerevisiae mixed with a commercial product (CP) of animal feed to assess its influence on the Aspergillus flavus and $A$. parasiticus fungi growth on the $\mathrm{AFB}_{1}$ production. Besides, $\mathrm{AFB}_{1}$ adsorption potential of $S$. cerevisiae and the commercial product was also investigated. Different concentrations of the commercial product alone and in the presence of inactivated yeast were analyzed by Aspergillus growth inhibition test, aflatoxin production by Aspergillus species, and $\mathrm{AFB}_{1}$ adsorption capacity. $\mathrm{AFB}_{1}$ detection and quantification were carried out by High-Performance Liquid Chromatography. The inactivated yeast and commercial product combination were effective in reducing $A$. flavus and $A$. parasiticus growth. A. flavus produced less $\mathrm{AFB}_{1}$ after the inactivated yeast treatment, whereas $A$. parasiticus produced significantly less $\mathrm{AFB}_{1}$ under a combination of inactivated yeast and $50 \%$ CP. Regarding $\mathrm{AFB}_{1}$ adsorption, $100 \% \mathrm{CP}$ displayed the highest adsorption capacity at $10 \mathrm{ng} \mathrm{mL} \mathrm{m}^{-1} \mathrm{AFB}_{1}$. At $25 \mathrm{ng} \mathrm{mL}^{-1} \mathrm{AFB}_{1}$, only the treatment comprising inactivated yeast associated with $50 \% \mathrm{CP}$ led to $\mathrm{AFB}_{1}$ adsorption, albeit at low levels. It was concluded that the association between the commercial additive and inactivated $S$. cerevisiae was effective in reducing the growth of fungi and there was $\mathrm{AFB}_{1}$ adsorption activity.
\end{abstract}

KEYWORDS: Inhibitory effect. Mycotoxin. Aspergillus flavus. Aspergillus parasiticus.

RESUMO: Saccharomyces cerevisae é uma levedura largamente utilizada como probiótico na aquicultura e que tem se destacado devido a capacidade para a descontaminaçáo de AFB1. O objetivo desse trabalho foi avaliar a atividade antifúngica e anti-aflatoxigênica da Saccharomyces cerevisae inativada e misturada a um produto comercial, observando sua influência no crescimento dos fungos Aspergillus flavus e A. parasiticus e na produção destes da Aflatoxina B1 (AFB1), investigar o potencial de adsorção da levedura e do produto comercial sobre a AFB1. Foram realizadas analises de preparação de leveduras inativadas e das soluçôes com o produto comercial, Ensaio do efeito inibitório de espécies de Aspergillus in vitro, Teste in vitro sobre a produçáo de aflatoxinas, avaliaçáo in vitro da capacidade de adsorçáo de AFB1, condições cromatográficas para detecção e quantificação de AFB1 por cromatografia Líquida de Alta Eficiência. A associação do aditivo comercial EPICIN - G2 ${ }^{\bullet}$ e a levedura S. cerevisiae inativada foi eficaz na diminuição do crescimento fúngico dos A. flavus e A parasiticus. Quanto à produção de micotoxina, o A. flavus obteve menor produção com o tratamento composto por leveduras inativadas, enquanto, o A. parasiticus teve diminuição significativa na produção de AFB1 com a associação da levedura a uma concentração de $50 \%$ do produto. No referente a adsorção, em concentraçáo de $10 \mathrm{ng} / \mathrm{mL}$, o tratamento que demonstrou melhor capacidade de adsorver AFB1 foi o 100\% Produto (100\%). Já na concentração $25 \mathrm{ng} / \mathrm{mL}$, somente o tratamento que associava levedura e $50 \%$ do produto, apresentou uma pequena capacidade de adsorção.

PALAVRAS-CHAVE: efeito inibidor. Micotoxina. Aspergillus flavus. Aspergillus parasiticus. 


\section{INTRODUCTION}

Fish nutrition has advanced significantly with the expansion of aquaculture activities worldwide, aiming at improving performance indices to meet fish nutritional requirements. However, this must be carried out by providing all the nutrients and energy necessary to optimize fish development by combining both quality and safety (SANTOS et al., 2015).

The presence of fungi in animal feed leads to economic losses, as these organisms are associated with nutrient reduction and palatability, as well as the production of mycotoxins by some species under favorable conditions, i.e. metabolic substances toxic to both humans and animals (PRESTES et al., 2019).

Mycotoxins produced by the fungi, Aflatoxins are produced naturally by Aspergillus flavus and Aspergillus parasiticus, classified as aflatoxins B1, B2, G1, G2, M1, and M2. These metabolites present similar structures and toxic effects, including acute hepatotoxicity, teratogenesis, immunosuppression, anemia, and decreased fertility, among others (COPETTI et al, 2011; ZYCHOWSKI et al., 2013). Anti-mycotoxin Additives (AAM) adsorbents, after inclusion in animal diets, display the ability to adsorb, inactivate, biotransform or neutralize mycotoxins, thus reducing their bioavailability within the gastrointestinal tract, avoiding harmful effects, followed by toxin elimination via feces (KELLER et al., 2012).

The yeast cell wall is a physical barrier that protects cells from environmental factors and is also used as a biological mycotoxin adsorbent to reduce their gastrointestinal absorption during feeding (BOROVIKOVA et al., 2016; PEREYRA et al., 2018). In this scenario, Saccharomyces cerevisiae has been highlighted as a probiotic applied in fish farming, poultry farming, and pig farming, and its cell wall components have been shown to act as growth promoters and immune system stimulants, as well as mycotoxin adsorbents (ROSSI et al., 2010).

In this context, the present study aimed to evaluate the antifungal and anti-aflatoxigenic activities of inactivated Saccharomyces cerevisiae, both isolated and mixed with a commercial product, and determine its effects on Aspergillus flavus and Aspergillus parasiticus growth and Aflatoxin $\mathrm{B} 1\left(\mathrm{AFB}_{1}\right)$ production. $\mathrm{AFB}_{1}$ adsorption potential was also investigated.

\section{MATERIAL AND METHODS}

Saccharomyces cerevisiae (strain A8L1) belonging to the culture collection of the Microbiological Control Laboratory of the Nucleus of Studies, Research and Food Processing (NUEPPA), UFPI. The commercial product (CP) of animal feed containing Bacillus subtilis, B. licheniformis, Lactobacillus acidophilus, $B$. pumilus, and Saccharomyces cerevisiae. Aflatoxin-producing fungi species Aspergillus flavus, it also belongs to the laboratory collection, and Aspergillus parasiticus NRLL 2999 (USDA, Agricultural Research Service, Peoria, IL) were used for the inhibitory tests.

Saccharomyces cerevisiae was inoculated into $250 \mathrm{~mL}$ Erlenmeyer flasks in $100 \mathrm{~mL}$ (YPD) broth (comprising $5 \mathrm{~g}$ yeast extract, $5 \mathrm{~g}$ peptone, $40 \mathrm{~g}$ dextrose, $1000 \mathrm{~mL}$ distilled water) and incubated under stirring $(150 \mathrm{rpm})$ at $25^{\circ} \mathrm{C}$ for 24 hours. After incubation, serial dilutions were then prepared in Falcon tubes using PBS (phosphate buffer - $\mathrm{pH}$ 7.2), until obtaining $10^{7}$ cells $\mathrm{mL}^{-1}$ concentration. The cell suspension concentration was determined using hemocytometer.

For inactivation of the yeast, Falcon tubes containing the yeast at concentrations of $10^{7}$ cells $\mathrm{mL}^{-1}$ were centrifuged at $3500 \mathrm{rpm}$ for five minutes, the supernatant was discarded and a further wash was performed with PBS, the resulting cell pellet was autoclaved at $120^{\circ} \mathrm{C}$ for 15 minutes.

Later, in the tube containing the cell pellet inactivated was transferred $10 \mathrm{~mL}$ of product solution prepared with PBS in different concentrations $(0 \%, 50 \%, 75 \%$, and $100 \%)$, and mixed to obtain homogeneous treatments.

For the in vitro inhibitory assay using both Aspergillus species was performed according to Juri et al. (2015) with minor modifications, the fungi were first cultured in Malt Extract Agar (MEA) at $25^{\circ} \mathrm{C}$ for seven days until complete sporulation and then maintained at $4^{\circ} \mathrm{C}$ until use. The in vitro bioanalytical method was applied, where the development or inhibition of fungi growth in the presence of the four applied treatments was observed. A total of $1 \mathrm{~mL}$ of each yeast and product experimental solution was added to $15 \mathrm{~mL}$ of previously autoclaved MEA at $120^{\circ} \mathrm{C}$ for 15 minutes.

After media solidification, a $7 \mathrm{~mm}$ center hole was drilled in the center of each plate and the spore solutions containing $4 \times 10^{6}$ spores $\mathrm{mL}^{-1}$ of each fungi species were added for each of the four treatments. Plates were then incubated at 25 ${ }^{\circ} \mathrm{C}$. Orthogonal measurements of colony diameters were carried out on the $3^{\text {rd }}$ and $7^{\text {th }}$ incubation days, using the development of each species cultured in MEA without any treatment as reference. All experiments were performed in duplicate (MUÑOZ et al., 2010; JURI et al., 2015).

The in vitro test concerning Aspergillus aflatoxin production was carried out using fungal colonies grown in MEA plates at $25^{\circ} \mathrm{C}$ for seven days in the inhibitory effect assay described above, followed by $\mathrm{AFB}_{1}$ detection and quantification by High-Performance Liquid Chromatography (HPLC).

Quantification was performed by SHIMADZU ${ }^{\circ}$ HighPerformance Liquid Chromatograph (HPLC), PROMINENCE model, with a SUPER RF-10AXL model fluorescence detector, $20 \mu \mathrm{L}$ loop, and excitation and emission of $360 \mathrm{~nm}$ and $460 \mathrm{~nm}$, respectively (TRUCKSESS et al., 1994). It was equipped with a C18 silica gel reverse phase column $(150 \mathrm{x}$ $4.6 \mathrm{~mm}, 5.0 \mu \mathrm{m}$ particle size, Phenomenex, Luna) connected to a Supelguard LC-ABZ precolumn $20 \times 4.6 \mathrm{~mm}, 5.0 \mu \mathrm{m}$ particle size, Supelco). The limit of detection of the analytical method was $0.4 \mathrm{ng} \cdot \mathrm{g}^{-1}$. $\mathrm{AFB}_{1}$ was quantified by HPLC using $200 \mu \mathrm{L}$ of each sample and $700 \mu \mathrm{L}$ of the derivatizing solution, composed of glacial acetic acid: water (trifluoroacetic acid: 20:10:70 v/v). Experiments were carried out in duplicate.

The quantifications of $\mathrm{AFB}_{1}$ adsorbed by yeast and commercial product mixtures will be performed by the following 
equation, where: $\mathrm{A}=(\mathrm{B}-\mathrm{C}) \times \mathrm{D} / \mathrm{E}$. Where $\mathrm{A}$ represents the amount (ng.mL-1) of toxin by the yeast mixture and commercial product; $\mathrm{B}$ is the height of the chromatographic peak of the sample; $\mathrm{C}$ is the height of the chromatographic peak of the negative control; $\mathrm{D}$ is the concentration $\left(\mathrm{ng} \cdot \mathrm{mL}^{-1}\right)$ of the positive control; and $\mathrm{E}$ refers to the height of the chromatographic peak of the positive control (PINHEIRO et al., 2017).

The $\mathrm{AFB}_{1}$ adsorption capacity assay was carried out using different concentrations of inactivated $S$. cerevisiae and $\mathrm{CP}$, as follows: $100 \%$ Yeast, Yeast $+50 \%$ CP, Yeast $+75 \%$ CP, and $100 \% \mathrm{CP})$. The experiments were performed under simulated fish gastrointestinal conditions (Nile tilapia, $\mathrm{pH}$ 7). A phosphatebuffered saline (PBS) was prepared to add sodium hydroxide $(0.1 \mathrm{~N} \mathrm{NaOH})$ until reaching $\mathrm{pH} 7$ (ROTTA, 2003). The assay was performed using two aflatoxin $\mathrm{B} 1$ concentrations (10 and $25 \mathrm{ng} \mathrm{mL}^{-1}$ ) at $\mathrm{pH} 7$ for the evaluation of the adsorption capacity of each treatment (PINHEIRO et al., 2020).

Before the assay, $1 \mathrm{ml}$ of each yeast and product experimental solutions were transferred to a microtube and centrifuged at $12000 \mathrm{rpm}$ for five minutes. The supernatants were then discarded and the pellets were washed twice with a PBS solution ( $\mathrm{pH}$ ) and incubated for 60 minutes at $37^{\circ} \mathrm{C}$ under constant agitation $(150 \mathrm{rpm})$, to simulate stomach conditions and promote contact between the toxin and the experimental solutions. After the incubation period, second centrifugation was carried under the same conditions as above, the supernatants were discarded and $1 \mathrm{~mL}$ of $\mathrm{AFB}_{1}$ was added at $\mathrm{pH} 7$. The incubation period was then repeated, followed by another centrifugation step and the supernatants were then transferred to other microtubes for quantification.

An analysis of variance (ANOVA) test was performed to verify the significance of the differences between treatments. The level of significance was set at 0.05 for multiple comparisons, and the Student Newman Keuls test was used when ANOVA pointed to the rejection of the hypothesis of equality between the treatment means. The Assistat version 7.7 software was used for all statistical analyses.

\section{RESULTS AND DISCUSSION}

Inactivated S. cerevisiae (A8L1), in association with the commercial additive, decreased the growth of A. flavus (A615) and A. parasiticus (NRLL 2999). However, no difference $(\mathrm{p}<0,05)$ was observed between the control sample and the inactivated yeast treatment (Table 1), indicating that inactive yeast alone is not effective in inhibiting Aspergillus growth.

Regarding A. flavus (A615), the control treatment presented a growth diameter means of $68 \mathrm{~mm}$, lower than that observed in the $100 \%$ yeast treatment, which on the $7^{\text {th }}$ day reached a means of $79.20 \mathrm{~mm}$.

The mixture of commercial additive and inactivated yeast had a similar effect on A. flavus growth inhibition than that of the commercial product alone $(\mathrm{p}<0.05)$. Both results remained below the minimum of $50 \mathrm{~mm}$ compared to fungi growth at the 7 th day on the control treatment dishes, demonstrating potentiation of the effect of the mixed treatment on A. flavus growth inhibition (Figure 1).

Concerning $A$. parasiticus (NRLL 2999), growth means ranged from $61,30 \mathrm{~mm}$ to $29.80 \mathrm{~mm}$, with no significant difference between the control and $100 \%$ S.cerevisiae treatments, similarly to $A$. flavus. According to Pitt and Hocking (2009), A. parasiticus in MEA for seven days presents a growth diameter ranging from 50 to $65 \mathrm{~mm}$. Therefore, the $100 \%$ yeast treatment presenting $60.50 \mathrm{~mm}$ was not effective in inhibiting fungal growth. The inactivated yeast associated with commercial additive, on the other hand, succeeded in inhibiting $A$. parasiticus growth (Figure 2). The most efficient treatment for both species was the association of Yeast $+75 \%$ commercial additive, with inhibited growth means of 39 $\mathrm{mm}$ (A. flavus) and $29.80 \mathrm{~mm}$ (A. parasiticus).

Table 2 displays the results for fungal $\mathrm{AFB}_{1}$ production. The addition of inactivated yeast decreased $A$. flavus mycotoxin

Table 1. Inactivated S. cerevisiae, $\mathrm{CP}$ and their interactions on the growth parameters of $A$. flavus and $A$. parasiticus strains on the $7^{\text {th }}$ day of the experiment.

\begin{tabular}{l|c|c}
\multirow{2}{*}{ Treatments } & \multicolumn{2}{|c}{$\begin{array}{c}\text { Growth rate }(\mathrm{mm}) \pm \text { Standard } \\
\text { deviation }\end{array}$} \\
\cline { 2 - 3 } & $\begin{array}{c}\text { Aspergillus } \\
\text { flavus } \\
\text { A6 15 }\end{array}$ & $\begin{array}{c}\text { Aspergillus } \\
\text { parasiticus } \\
\text { NRLL 2999 }\end{array}$ \\
\hline Control & $68,0^{\mathrm{a} \pm 16,90}$ & $61,3^{\mathrm{a}} \pm 14,00$ \\
\hline $\begin{array}{l}\text { 100\% } \\
\text { S.cerevisiae }\end{array}$ & $79,2^{\mathrm{a}} \pm 3,89$ & $60,5^{\mathrm{a}} \pm 13,10$ \\
\hline $\begin{array}{l}\text { S.cerevisiae } \\
+50 \% \text { product }\end{array}$ & $43,0^{\mathrm{b}} \pm 2,12$ & $30,8^{\mathrm{b}} \pm 3,00$ \\
\hline $\begin{array}{l}\text { S.cerevisiae } \\
+75 \% \text { product }\end{array}$ & $39,0^{\mathrm{b}} \pm 2,12$ & $29,8^{\mathrm{b}} \pm 4,00$ \\
\hline 100\% product & $39,7^{\mathrm{b}} \pm 0,35$ & $32,6^{\mathrm{b}} \pm 4,60$ \\
\hline
\end{tabular}

The averages followed by the same letter in the same column do not differ statistically fromeachother, by the StudentNewmanKeuls Test $(p<0,05)$. Source: author's collection.

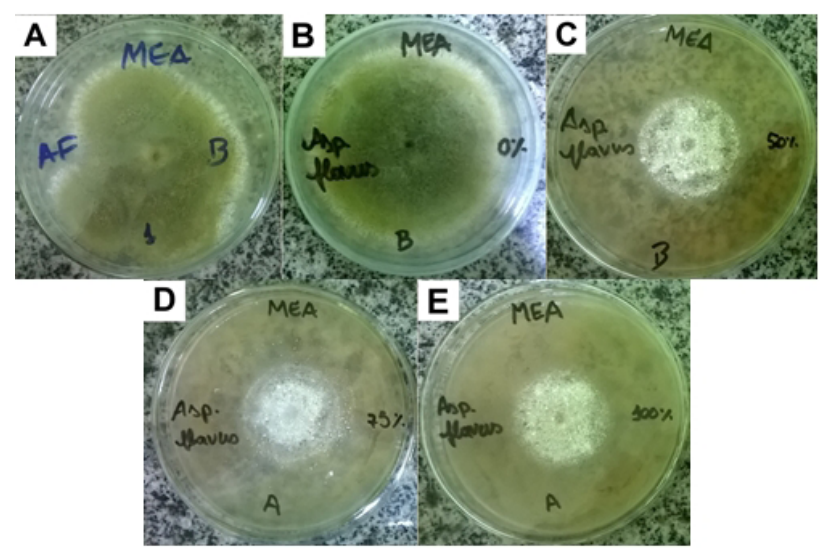

Source: author's collection.

Figure 1. A. flavus seeded in MEA under different treatments: A) Control, B) $100 \%$ S.cerevisiae, C) S.cerevisiae $+50 \%$ Product, D) S.cerevisiae + $75 \%$ Product E) $100 \%$ Product. 
production, with a significant difference between the control treatment and the $100 \%$ S.cerevisiae treatment. A. flavus produced $2.77 \mu \mathrm{g} \mathrm{AFB}_{1}$ in the latter; the lowest yield obtained in all experiments, thus demonstrating that inactivated yeast is effective in inhibiting $\mathrm{AFB}_{1}$ production by $A$. flavus.

For A. flavus (A615), the lowest toxin synthesis was observed in the $100 \%$ S.cerevisiae treatment, where fungal

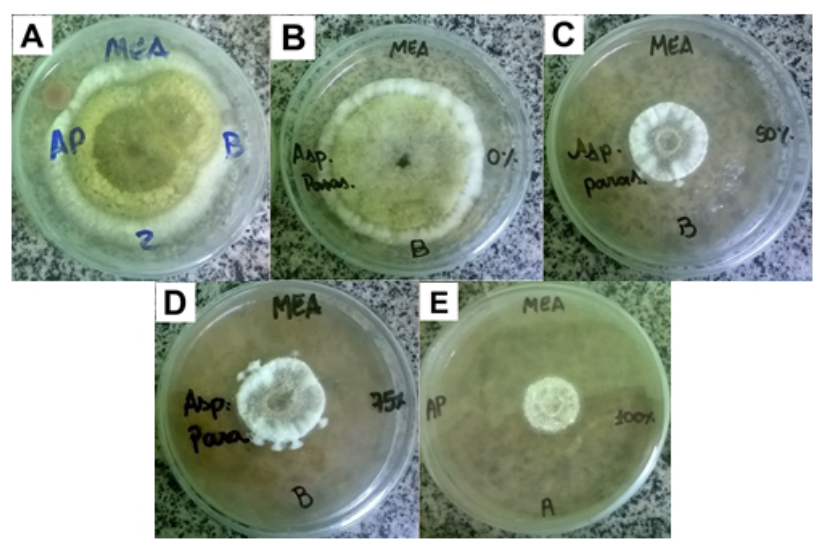

Source: author's collection.

Figure 2. A. parasiticus seeded in MEA under different treatments. A) Control, B) $100 \%$ S.cerevisiae, C) S.cerevisiae + $50 \%$ Product, D) S.cerevisiae + $75 \%$ Product E) $100 \%$ Product.

Table 2. A. flavus and A. parasiticus $\mathrm{AFB}_{1}$ production in the presence of inactivated $S$. cerevisiae and $\mathrm{CP}$.

\begin{tabular}{|c|c|c|}
\hline \multirow{2}{*}{ Treatments } & \multicolumn{2}{|c|}{$\begin{array}{c}\text { AFB }\left(\mathbf{u g} \cdot \mathrm{g}^{-1}\right) \pm \\
\text { Standard deviation }\end{array}$} \\
\hline & $\begin{array}{c}\text { Aspergillus } \\
\text { flavus }\end{array}$ & $\begin{array}{l}\text { Aspergillus } \\
\text { parasiticus }\end{array}$ \\
\hline Control & $38,1^{a} \pm 3,7$ & $634,4^{a} \pm 361,3$ \\
\hline 100\% S.cerevisiae & $2,7^{\mathrm{b}} \pm 3,7$ & $503,0^{a} \pm 65,1$ \\
\hline S.cerevisiae $+50 \%$ product & $7,2^{b} \pm 4,0$ & $2,93^{b} \pm 1,6$ \\
\hline S.cerevisiae $+75 \%$ product & $5,2^{\mathrm{b}} \pm 3,9$ & $41,6^{b} \pm 21,5$ \\
\hline $100 \%$ product & $8,4^{b} \pm 0,9$ & $4,5^{\mathrm{b}} \pm 4,0$ \\
\hline
\end{tabular}

The averages followed by the same letter in the same column do not differ statistically from each other, by the Normality Test $(p<0,05)$. The mean comparison test was not applied because the interaction $F$ was not significant. growth exceeded the means established by Pitt and Hocking (2009) for this fungi species. This can be explained by a low aflatoxigenic capacity of the A. flavus strain and by the compounds present in the cell wall of $S$. cerevisiae, such as $\beta$-glucans and mannoproteins that are associated with the reduction of toxin production (ABDOLSHAHI et al., 2018).

For A. parasiticus (NRLL 2999), results were similar to those reported by Gerbaldo et al. (2012), as the lowest mycotoxin production was observed in the S. cerevisiae + 50\% commercial additive, where the lowest growth means were observed.

Different commercial product concentrations led to good results, with a slightly higher $\mathrm{AFB}_{1}$ production than $100 \% S$. cerevisiae addition, with no difference between treatments. $A$. parasiticus in the treatment $100 \%$ S.cerevisiae, showed a high mycotoxin production, as well as the fungi, were grown in a petri dish containing MEA (Control).

A significant decrease in $\mathrm{AFB}_{1}$ production for $\mathrm{A}$. flavus was observed in the $100 \%$ yeast treatment. The S. cerevisiae $+75 \%$ product treatments led to increased $\mathrm{AFB}_{1}$ synthesis for $A$. parasiticus.

S. cerevisiae has been reported as capable of inhibiting $A$. flavus and $A$. parasiticus $\mathrm{AFB}_{1}$ production (ARMANDO et al. 2012; BOVO et al., 2010). In addition to being a well-known probiotic capable of preventing absorption in the gastrointestinal tract (AZEEM et al. 2019).

In another study, Abdolshahi et al. (2018), used S. cerevisiae mannoprotein to coat pistachio samples demonstrating that the presence of yeast caused a decrease and delay in sporulation in all pistachio samples inoculated with A. flavus, with the appearance of mycelia and conidia after 5 days incubation compared to the control group, that is, without mannoprotein. When evaluating the production of $\mathrm{AFB}_{1}$, he also observed that there was less production of total aflatoxin and $\mathrm{AFB}_{1}$ in samples containing yeast, the higher the concentration of yeast, the greater the decrease in the production of toxin.

Two $\mathrm{AFB}_{1}$ concentrations, 10 and $25 \mathrm{ng} \mathrm{mL}^{-1}$ were used in the adsorption test. Variations between treatments were observed, where negative results were considered as no adsorption. At 10 $\mathrm{ng} / \mathrm{mL}$, two treatments demonstrated the ability to adsorb $\mathrm{AFB}_{1}$, namely S.cerevisae $+75 \%$ Product and 100\% Product, with adsorption rates of $12.93 \%$ and $21.08 \%$, respectively (Table 3).

Table 3. AFB ${ }_{1}$ adsorption percentages by inactivated S. cerevisiae and commercial additive.

\begin{tabular}{|c|c|c|c|c|}
\hline \multirow{3}{*}{ Treatments } & \multicolumn{4}{|c|}{ Aflatoxin B 1} \\
\hline & \multicolumn{2}{|c|}{$10 \mathrm{ng} / \mathrm{mL}$} & \multicolumn{2}{|c|}{$25 \mathrm{ng} / \mathrm{mL}$} \\
\hline & Mean & Deviation & Mean & Deviation \\
\hline $100 \%$ S.cerevisae & $N A^{b}$ & $\pm 8,6$ & $N A^{a}$ & $\pm 7,6$ \\
\hline S.cerevisae $+50 \%$ product & $N A^{b}$ & $\pm 1,0$ & $3,59^{a}$ & $\pm 12,6$ \\
\hline S.cerevisae $+75 \%$ product & $12,9^{\mathrm{a}}$ & $\pm 7,5$ & $\mathrm{NA}^{a}$ & $\pm 4,2$ \\
\hline $100 \%$ product & $21,0^{a}$ & $\pm 8,4$ & $N A^{a}$ & $\pm 27,4$ \\
\hline
\end{tabular}

The averages followed by the same letter do not differ statistically from each other, by the Normality Test $(p<0,05)$. The mean comparison test was not applied because the interaction F was not significant. NA: No Adsorption. 
The treatment composed solely of commercial additive was the most effective at adsorbing $\mathrm{AFB}_{1}$ at $10 \mathrm{ng} / \mathrm{mL}$. As demonstrated in other studies, the use of $S$. cerevisiae cell wallbased additives sterifies glucomannans capable of binding to $\mathrm{AFB}_{1}$. The results reported by Pinheiro et. al. (2017) using a product anti mycotoxin additive from brewer's yeast, demonstrated that the highest amount of mycotoxin was adsorbed at $100 \%$ product concentration. Dawson, Evans, and Kudupoje (2006) reported up to $85 \%$ aflatoxin adsorption using only YCW-based products. In another study, Pinheiro et. al. (2015) when comparing the binding capacity of two additives against Ochratoxin A (OTA), one based on lactic acid bacteria associated with Bacillus sp. and another composed of dried S. cerevisiae, noted that the dry yeast commercial product was more efficient at adsorbing OTA (24.8 to $31.8 \%$ ) than lactic acid bacteria associated with Bacillus sp. (1.2 to 7.7\%), reporting the most efficient concentration as $100 \%$. Concerning $25 \mathrm{ng} /$ $\mathrm{mL} \mathrm{AFB}_{1}$, the only treatment with positive adsorption results was Yeast $+50 \%$ Product, leading to $3.59 \%$ adsorption.

The inactivated yeast treatment showed no adsorption capacity for both $\mathrm{AFB}_{1}$ concentrations, indicating that inactivated S. cerevisiae (A8L1) displays no ability to bind to $\mathrm{AFB}_{1}$.
However, at $25 \mathrm{ng} / \mathrm{mL}$, S. cerevisiae (A8L1) associated with commercial products demonstrated the ability to adsorb $\mathrm{AFB}_{1}$, although this was not effective at the lowest $\mathrm{AFB}_{1}$ concentration. Another factor that could justify the inability of the inactivated yeast to adsorb the investigated $\mathrm{AFB}_{1}$ concentrations could be the experimental contact time, since Piotrowska and Zakowska (2005), when working with Lactobacillus, obtained $70 \%$ and $87 \%$ adsorption after five days of bacteria incubation at $37^{\circ} \mathrm{C}$ with OTA, demonstrating that the contact period between the toxin and the biological product increases toxin removal rates. Another important aspect was studied by Bejaoui et al. (2004), who reported that the addition of acid and heat increased adsorption rates to $75 \%$, hypothesizing that the formed complex is more stable under these conditions, thus indicating the physical nature of the bond.

\section{CONCLUSIONS}

It was concluded that the association between the commercial additive and inactivated S. cerevisiae was effective in reducing the growth of fungi. The production of mycotoxins by $A$. flavus and $A$. parasiticus showed a reduction for some treatments, and although low, there was also the $\mathrm{AFB}_{1}$ adsorption activity.

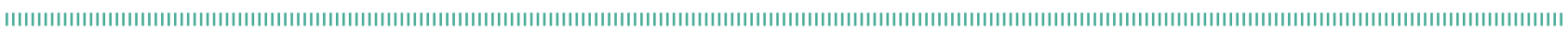
REFERENCES

ABDOLSHAHI, A., et al. Antifungal activities of coating incorporated with Saccharomyces cerevisiae cell wall mannoprotein on Aspergillus flavus growth and aflatoxin production in pistachio (Pistacia vera L.). Journal of Food Safety, 2018.

ARMANDO, M. R., et al. Saccharomyces cerevisiae strains and the reduction of Aspergillus parasiticus growth and aflatoxin B 1 production at different interacting environmental conditions, in vitro. Food Additives \& Contaminants: Part A, v.29. n. 9, p. 14431449, 2012.

AZEEM, N. et al. Activity and Anti-Aflatoxigenic Effect of Indigenously Characterized Probiotic Lactobacilli against Aspergillus flavus - A Common Poultry Feed Contaminant. Animals. v. 9. p. $166,2019$.

BEJAOUI, H., MATHIEU, F., TAILLANDIER, P., LEBRIHI, A. Ochratoxin A removal in synthetic and natural grape juices by selected oenological Saccharomyces strains. Journal of Applied Microbiology. v.97, p.1038-1044. 2004.

BOROVIKOVA, D. et al. Anhydrobiosis in yeast: cell wall mannoproteins are important for yeast Saccharomyces cerevisiae resistance to dehydration. Yeast. 33(8), 347-353. 2016.

BOVO, F. et al. Descontaminação de aflatoxinas em alimentos por bactérias ácido-láticas. Revista Unopar Científica Ciêncas Biológicas e da Saúde. v. 12. p. 15-21, 2010.

COPETTI, M.V. et al. Aflatoxigenic fungi, and aflatoxin in cocoa, International Journal of Food Microbiology, v. 148, p. 141-144. 2011.

DAWSON, K. A., EVANS, J., KUDUPOJE, M. Understanding the adsorption characteristics of yeast cell wall preparations associated with mycotoxin binding. In: Nutritional Biotechnology In The Feed And Food Industries, 22, 2006, Lexington, Proceedings... Lexington: Alltech, p. 169-181. 2006.

GERBALDO, G.A. et al. Antifungal activity of two Lactobacillus strains with potential probiotic properties. FEMS Microbiol. Lett. 332. p. 27-33. 2012.

JURI, M.G.F., et al. In vitro aflatoxin B 1 binding capacity by two Enterococcus faecium strains isolated from healthy dog faeces. Journal of Applied Microbiology 1 18:3, pages 574-582. 2015.

KELLER, K.M., et al. Effect of yeast cell wall on the productive performance of broiler chickens intoxicated with Aflatoxin B1. Revista Brasileira de Medicina Veterinária, v. 34, n. 2, p. 101 105. 2012.

MUÑOZ, R., et al. Inhibition of mycotoxin-producing Aspergillus nomius vsc 23 by lactic acid bacteria and Saccharomyces cerevisiae. Brazilian Journal of Microbiology. 41: 10191026. 2010.

PEREYRA, C.M., et al. The production of yeast cell walls using an agro-industrial waste influence the wall thickness and is implicated in the aflatoxin B 1 adsorption process. Food Research International, 111, 306-313.2018.

PRESTES, I. D. et al. Fungi and mycotoxins in corn grains and their consequences. Scientia Agropecuária 10(4): 559-570. Scientia Agropecuária 10(4): 559 -570. 2019.

PINHEIRO, R.E.E. et al. In vitro “in vitro" adsorption of ochratoxin by probiotics used in aquaculture. Acta Veterinária Brasílica, v.9, n.1, p.59-64. 2015. 
PINHEIRO, R.E.E., et al. In vitro evaluation of the adsorption of ochratoxin $\mathrm{B} 1$ by commercial products used in animal feed. Arq. Inst. Biol., v.84. p. 1-6. 2017.

PINHEIRO, R.E.E. et al. Saccharomyces cerevisiae as a probiotic agent and a possible aflatoxin B1 adsorbent in simulated fish intestinal tract conditions. Arq. Bras. Med. Vet. Zootec., Belo Horizonte, v.72, n.3, p. 862-870, May 2020.

PIOTROWSKA, M.; ZAKOWSKA, Z. The elimination of ochratoxin $A$ by lactic acid bacteria strains. Polish Journal of Microbiology. v.54, p.279-286. 2005.

PITT, J. I., HOCKING, A. D. Fungi and spoilage. 2 ed. London: Blackie Academic and Professional. 2009.

ROSSI, P. et al. Effect of the esterified glucomannan-based sorbent on performance and visceral characterization of broilers. Revista Brasileira Agrociência, v. 16, n. 1-4, p. 91-100. 2010.
ROTTA, M. A. General aspects of the physiology and structure of the digestive system of fish related to fish farming. Corumba: Embrapa Pantanal, 48p. 2003.

SANTOS, S. K. A. et al. Microalga Schizochytrium sp. in Rations for Nile Tilapia. Caderno de Ciências Agrárias, 7 , 75-79. 2015.

TRUCKSESS, M.W. et al. Multifunctional column coupled with liquid chromatography for determination of aflatoxins B1, B2, $\mathrm{G} 1$, and $\mathrm{G} 2$ in corn, almonds, Brazil nuts, peanuts, and pistachio nuts: collaborative study. Journal of AOAC International. v. 77. p. $1512-1521.1994$.

ZYCHOWSKI, K. E., et al. The effect of NovaSil dietary supplementation on the growth and health performance of Nile tilapia (Oreochromis niloticus) fed aflatoxin-B1 contaminated feed. Aquaculture, Amsterdam, v. 376, p. 117-123, 2013. 